\title{
Bioehanol Production from Bulrush with A Combination of Chemical and Biological Process
}

\author{
[ Sari Ni Ketut ]
}

\begin{abstract}
Bulrush is a plant that is available abundantly however it has not been utilized well. During this time, it was utilized just as animal feedstock, even it is considered as weeds. Bulrush has cellulose, glucose, and starch content that can be used as material of ethanol production. This research was aimed to review hydrolysis process, fermentation process, batch distillation process, and search for alternative material for bioethanol production. In bioethanol making process, three processes were done such hydrolysis process biologically by using enzyme and chemically by using HCl.While fermentation process used Saccharomyces Cerevisiae and batch distillation. After those three processes were done, high level of bioethanol content was obtained in $95 \%-96 \%$ and it could be concluded that bulrush can be used as alternative material of bioethanol production.
\end{abstract}

Keywords - bioethanol, bulrush, hydrolysis, fermentation, batch distillation

\section{Introduction}

Biomass from plants has been declared as an alternative raw material for gasoline fuel substitution in the form of bioethanol, bioethanol obtained from biomass and bioenergy crops has been proclaimed as one of the feasible alternative as gasoline fuel [1]. Environmental sustainability of bioethanol from rice straw[2]. The technology for lignocellulose ethanol production relies mainly on pretreatment, chemical or enzymatic hyhrolysis, fermentation and product separation or distillation. An appropriate pretreatment strategy is essential for the efficient enzyme hydroysis of lignocellulosic biomass as lignin hinders the saccharification process. Various pretreatment approaches have been exploited in the past such as acid or alkali pretreatment, hydrogen peroxide pretreatment, steam explosion, liquid hot water, ammonia fiber expansion pretreatment, sodium chorite pretreatment, and biological pretreatment [3].

The research conducted to evaluate acid pretreatment from hydroside paper waste as material for bioethanol production, optimized sulfuric acid hydrolysis, fermentation process of hydroside acid of paper waste by using Pichia stipitis. The ethanol content was obtained of $77.54 \%$. By one more distillation process, the ethanol content will be obtained in the level of 95-96\% [4]. Chemical pretreatment of lignocellulosic biomass with Sulphuric $\left(\mathrm{H}_{2} \mathrm{SO}_{4}\right)$ and phosphoris $\left(\mathrm{H}_{3} \mathrm{PO}_{4}\right)$ acids are widely used since they are relatively cheap and efficient in hydrolysing lignocellulose, though the letter gives a milder effect and is more benign to the environment.

Sari Ni Ketut

Universitas Pembangunan Nasional "Veteran" Jawa Timur Indonesia
Hydrochloric $(\mathrm{HCl})$ acid is more volatile and easier to recover and attacks biomass better than $\mathrm{H}_{2} \mathrm{SO}_{4}$ [5], similarly, nitric acid (HNO3) posseses good cellulose to sugar conversion rates [6]. However, both acids are expensive compared to sulphuric acid.

Pretreatment of lignocellulose has received considerable research globally due to its effluence on the technical, economic and enviromental sustainability of cellulose ethanol production. This paper reviews know and emerging chemical pretreatment methods, the combination of chemical pretreatment with other methods to inprove carbohydrate preservationreduce formation to degradation product, achieve high sugar yield at mild reaction conditions, reduce solvent loads and enzyme dose, reduce waste generation [7]. Technical and economical avaluation of bioethanol production from lignocellulosic residues, case of sugarcane and blue agave bagasses [8].

Initiatives of the future for lignin in biomass to bioethanol, pretreatment technologies to separate the tree main biopolimers (cellulose, hemicellulose, and lignin) [9]. Pretreatment for hydrogen and bioethanol production from olive oil waste products was ethanol yield $5.4 \%$ treatment with $1.75 \mathrm{w} / \mathrm{v}$ sulphuric acid and heated it at $140{ }^{\circ} \mathrm{C}$ for 10 min, and was ethanol yield $5.0 \%$ no pretreatment [10]. Pretreatment followed with simultaneous saccharification and fermentation on bioconversion of microcrystalline cellulose for bioethanol production, the yield value of $67 \%$ bioethanol bioconversion [11]. A sustainable feedstock bioethanol production, cellulose hydrolysis was microwave irradition using hydrochloric acid as catalyst, fermentation with yeast (Saccharomyces cerevisiae), modest reaction conditions (2.38 $\mathrm{M}$ acid consentration), irradition time 7 min, and yield of $0,67 \mathrm{~g}$ glucose / $\mathrm{g}$ cellulose [12].

The glucose forming reaction from cellulose is as following:

$$
\left(\mathrm{C}_{6} \mathrm{H}_{10} \mathrm{O}_{5}\right)_{\mathrm{n}}+\mathrm{n} \mathrm{H}_{2} \mathrm{O} \longrightarrow \mathrm{nC}_{6} \mathrm{H}_{12} \mathrm{O}_{6}
$$

Elements contained in the lignocellulose biomass of the plants are usually used lignocellulose biomass, potential for bioethanol production globally. Agriculture (soft wood), forestry (hard wood), and industrial waste are a major lignocellulose biomass for bioethanol production. The lignocellulosic biomass is one of the potential main sources for economic bioethanol production globally. Agricultural, forestry (soft and hardwoods) and industrial wastes are the major lignocellulosic biomasses [13]. The lignocellulosic biomass for bioethanol production was developed using inhibitors-tolerant Saccharomyces cerevisiae, more than $4 \%$ (w/w) ethanol consentration was achieved, which corresponded to $72.3 \%$ theoretical yield of ethanol [14]. Bioethanol production using sodium hydroxide pretreated sweet sorghum bagasse without washing, ethanol theoretical yield from $44.06 \pm 0.93 \%$ to $65.14 \pm 0.91 \%$ [15] 
The fermentation process is affected by microorganism that needs good nutrition in order to obtain a good result of fermentation. Proper nutrition to supply microorganisms is nitrogen which can be obtained from the addition of $\mathrm{NH}_{3}$, ammonium salts, peptone, amino acids, and urea. Liquid nitrogen that is needed is $400-1000$ gram/1000 lt. Phosphate is needed for 400 gram/1000 lt [16] in the fermentation process, glucose from fermentation process is converted into ethanol by the following reaction:

$$
\mathrm{C}_{6} \mathrm{H}_{12} \mathrm{O}_{6} \longrightarrow 2 \mathrm{C}_{2} \mathrm{H}_{5} \mathrm{OH}+2 \mathrm{CO}_{2}
$$

To increase the fermented sugar concentration after enzyme saccharification, conversion of glucose and xylose into ethanol needs a new fermentation technology [17]. The bioethanol production from lignocellulose biomass using process pretreatment, hydrolysis, fermentation and recovery of ethanol, was obtained by ethanol under $16 \% \mathrm{v} / \mathrm{v}$, with the distillation process will again be derived ethanol 95-96\% $\mathrm{v} / \mathrm{v}$. The research conducted bioethanol production from lignocellulose biomass by using pretreatment process, hydrolysis, fermentation and ethanol recovery. Therefore, ethanol content was obtained in the level below $16 \%$, and by one more distillation process the ethanol content would be obtained in the level of $95-96 \% \mathrm{v} / \mathrm{v}$ [18].

The research conducted by [19] about bioethanol production from agricultural waste using PROFER pretreatment method obtained ethanol content below $16 \%$. The purpose of dilute acid pretreatment is the removal of hemicelluloses and the recovery of the sugar component. Among all pretreatment methods, the acid pretreatment methods of biomass with dilute sulfuric acid has long been recognized as a critical step of removing the hemicellulosic fraction from the lignocellulosic substrate to economize the biological conversion of cellulosic biomass to ethanol [20]. The research conducted by [21] about ethanol production from sago pith waste (SPW) using microwave hydrothermal hydrolysis catalyzed by carbon dioxide, resulted in higher energy saving compared to previous techniques in the absence of enzymes, acid or base catalyst. They obtained ethanol content below $15.6 \%$.

The production of bioethanol from cashew apple juice, bioethanol consentration evaluate with fermentation by microorganism Saccharomyces cerevisiae Y2084 and Vin 13. The maximum ethanol concentration achieved by Y2084 was $65.00 \mathrm{~g} / \mathrm{L}$ and by Vin13 was $68.00 \mathrm{~g} / \mathrm{L}$, and fermentation time was 2 days [22]. Bioethanol produvtion from paper fibre residue using diluted $\mathrm{NaOH}$ and the fermentation process with microorganism Pinicillium Chrysogenum and Saccharomyces Cerevisiae. The fermentability of the hydrolysate decreased strongly for hydrolysate produced at temperature higher than $50{ }^{\circ} \mathrm{C}$, The ethanol consentration of monosaccharide hydrolysate was found to be $34.06 \mathrm{~g} / \mathrm{L}$ and ethanol yield was $0.097 \mathrm{~g} / \mathrm{g}$ [23]. Simultaneous biohydrogen and anaerobic fermentation with Immobilized sludge for production bioethanol with continous stired tank reaktor (CSTR), the hight $\mathrm{H}_{2}$ production rate $(10.74 \mathrm{mmol} / \mathrm{h} . \mathrm{L})$ and ethanol production rate (11.72 mmol/h.L) [24].

The equation (1) is a model of Differential-AlgebraicEquations (DAEs) for simple batch distillation of multicomponent systems, that there is no phase which forms two liquids, the vapor composition was calculated by using BUBL T equation [25].

Bioethanol production from lignocellulosic biomass involves different step such as pretreatment, hidrolysis, fermentation and ethanol recovery [26]. The technology for lignocellulosic ethanol production relies mainly on pretreatment, chemical or enzymatic hyhrolysis, fermentation and product separation or distillation. An appropriate pretreatment strategy is essential for the efficient enzyme hydroysis of lignocellulosic biomass as lignin hinders the saccharification process. Various pre-treatment approaches have been exploited in the past such as acid or alkali pretreatment, hydrogen peroxide pretreatment, steam explosion, liquid hot water, ammonia fiber expansion pretreatment [27]. Bioethanol production from sagu pith waste (SPW) using Hydrolysis by carbon dioxide, a maximum of $43.8 \%$ glucose and $40.5 \%$ ethanol yield, the develoved technique for SPW resulted in higher energy saving compared to previous techniques in the absence of enzymes, acid or base cataluyst [28].

Cellulosic or second generation (SG) bioethanol is produced from lignocellulosic biomass (LB) in three main steps: pretreatment, hydrolysis, and fermentation. Pretreatment involves the use of physical processes, chemical methods, physico-chemical processes, biological methods, and several combinations there of to fractionate the lignocellulose into its components. It result in the disruption of lignin seal to increase enzyme access to holocellulose [29,30], reduction of cellulose crystallinity $[31,32]$, and increase in the surface area [33, 34] and porosity $[35,36]$ of pretreated substrates, resulting in increased hydrolysis rate. In hydrolysis, cellulose and hemicelluloses are broken down into monomeric sugars via addition of acids or enzymes such as cellulase. Enzymatic hydrolysis offers advantages over acids such as low energy consumption due to the mild process requirement, high sugar yield, and no unwanted wastes. Enzymatic hydrolysis of cellulose affected by properties of the substrate such as porosity, cellulose fibre crystallinity, and degree of polymerization, as well as lignin and hemicellulose ontent [37, 38], optimum mixing [39], substrate and end-product consentration, enzyme activity, reaction conditions such as $\mathrm{pH}$ and temperature [40, 41].

From the previous research, it was known that bioethanol from cellulose resulted good bioethanol. The aim of this research was to search alternative material, review hydrolysis process, fermentation process, and distillation batch process to gain bioethanol product with high level of ethanol. The originality of this research was the second generation that was bulrush, by using three processes (hidrolysis, fermentation, and batch distillation) simultaneously and technical ethanol production with level of $95-96 \%$ as the substitution material of bioethanol.

\section{Experimental}

From the result of laboratory analysis, it was known that ethanol forming elements were cellulose, glucose and starch. The average concentration of cellulose was $48 \%$, glucose was $5 \%$ and starch was $20 \%$. 
The cutting of bulrush with approximately length of $5 \mathrm{~cm}$ was done in order to obtain the high level of glucose and cellulose during hydrolyzed process by bacillus and $\mathrm{HCl}$. The quality of bioethanol product was determined by various influencing parameter such as the acidity $(\mathrm{pH})$, the volume ratio of $\mathrm{HCl}$ to bulrush, and the volume ratio of Bacillus to filtrate, SC starter concentration, fermentation time, and batch distillation time.

The quality analysis of raw materials and bioethanol product was done by laboratory analysis. The analysis was conducted on the instrumentation and gravimetric analysis by using Gas Chromatography (GC) and Spectrophotometer, which analyzed items were the concentration of starch, glucose, ethanol, $\mathrm{HCl}$, crude protein level, and $\mathrm{N}, \mathrm{P}, \mathrm{K}, \mathrm{Ca}$, $\mathrm{Mg}, \mathrm{S}$.

\section{A. Procedure of Hydrolysis Process}

Hydrolysis process in Figure $\mathbf{1}$ was done in stable condition : temperature of $30{ }^{\circ} \mathrm{C}$, water volume in 7 liters, and hydrolysis time in 1 hour with 200 rotations per minute (RPM). For the changing condition: bulrush weight of 50, $100,150,200,250$ (grams), the ratio of bacillus to filtrate volume $1: 2 ; 5: 4 ; 10: 7$ and $\mathrm{HCl}$ solution volume $10,20,30$, 40, 50 (ml). The level of glucose in hidrolysis filtrate yield was analyzed before the fermentation process was done.

\section{B. Procedure of Fermentation Process}

The addition process of citrate acid and $\mathrm{NaOH}$ to the glucose yield from hydrolysis process which is unqualified the requirements was done. Then citrate acid was added to the hydrolysis filtrate yield which would be fermented until reach the approximate fermentation acidity $(\mathrm{pH})$ of 4,5 . Next, starter was put into the solution that would be fermented in anaerobic condition then sealed tightly the bottle and observed during certain time. In fermentation process such Figure 1, the stable conditions were the temperature of $30{ }^{\circ} \mathrm{C}$, acidity $(\mathrm{pH})$ of 4,5 ; the volume of fermentation was the same amount as the volume of hydrolysis process filtrate. The changing condition were fermentation time 4, 5, 6, 7, 8 (days), starter $8,10,12(\%)$, then the ethanol content was analyzed.

\section{Procedure of Distillation Process}

The yield of fermentation was put in distillation flask in order to obtain the ethanol from glucose. Batch distillation showing in Figure $\mathbf{1}$ was conducted on temperature of $78{ }^{\circ} \mathrm{C}$, completed by total condensor and gas stove heating. After the bottom solution volume remained $10 \%$ from its initial volume, the distillation process was stopped then the ethanol content was analyzed.

\section{Result and Discussion}

\section{A. Quality Raw Materials}

Bulrush using as a study material was derived from bulrush crops in the surrounding area. Assessment method was done by doing a survey and laboratory analysis to obtain some data about the quality and quantity of the available bulrush. The expected result was data about the quality and quantity of bulrush before processing to be an ethanol.

Based on the results of laboratory analysis, it was known that ethanol forming elements were cellulose, glucose and starch. The average concentration of cellulose was $48.1 \%$, glucose was $4.8 \%$ and starch was $20.4 \%$. If the entire cellulose can be hydrolyzed completely, it will be obtain the glucose levels of $53 \%$.

The cutting of bulrush with approximately length of 5 $\mathrm{cm}$ was done in order to obtain the high levels of glucose and cellulose before it was hydrolyzed by bacillus and $\mathrm{HCl}$ solution. Bulrush should be made in powder form, so cellulose can be hydrolyzed perfectly. However that process took an higher cost. Besides, bulrush in the powder form could suffer the physical destruction, thus causing the damage of glucose group. The drying process of bulrush was naturally done first in the room temperature. The drying process was done in an oven at $100^{\circ} \mathrm{C}$ for 3 hours. This was done for cost savings. The drying process aimed to reduce the water content in ethanol. Water level that was permitted by Standart National Indonesia (SNI) was $1 \%$.

The decreasing of $\mathrm{pH}$ from pretreatment material was affected by the addition of $\mathrm{HCl}$ volume $7 \% \mathrm{v} / \mathrm{v}$ because the requiring $\mathrm{pH}$ for fermentation process was 4,5 . Before doing the hydrolysis process, the $\mathrm{pH}$ of filtrate was measured according to the terms of fermentation process that is approximately 4.5. To obtain $\mathrm{pH} 4.5$, the addition of $\mathrm{Na}-\mathrm{OH}$ was done if $\mathrm{pH}$ of the filtrate was under 4.5 and the addition of citric acid if the filtrate $\mathrm{pH}$ was above 4.5.

\section{B. Hydrolysis Process}

In acid hydrolysis, $\mathrm{HCl}$ or $\mathrm{H}_{2} \mathrm{SO}_{4}$ was commonly used in certain level. Hydrolysis was usually done in a special tank made of stainless steel or copper pipe connected to the heating ducts and exhaust pipes in order to regulate the air pressure (Kuhad et al., 2010). The cellulose content of bulrush could be converted into glucose by concentrated acid hydrolysis process with certain concentration.

Figure 2 showed hydrolysis process was done by the various weight of bulrush: $50100,150,200$, and 250 (grams) by the addition of the various $\mathrm{HCl}$ volumes: 10, 20, $30,40,50 \mathrm{ml}$. After the extraction process was finished thus the solid and filtrate were obtained. The filtrate will be processed by the fermentation process to obtain ethanol concentration and solids can be used as compost. The effect of $\mathrm{pH}$ was essential in the fermentation process so filtrate must be measured for $\mathrm{pH}$ in the minimum level of 3,5 until the maximum level of 4,5 , because $\mathrm{SC}$ can be survived on that range of $\mathrm{pH}$. To maintain $\mathrm{pH}$ in 4.5 , the addition of $\mathrm{NaOH}$ would be done if filtrate $\mathrm{pH}$ was under 4.5 and the addition of citric acid would be done if the $\mathrm{pH}$ of the filtrate was above 4.5 .

The effect of glucose concentration in $20 \mathrm{ml} \mathrm{HCl}$ volume to bulrush weight was higher, on 250 grams bulrush and 20 $\mathrm{ml} \mathrm{HCl}$ volume will be gained the glucose concentartion of $37,8 \%$. Therefore, before fermentation process was done, the maximum level of optimum glucose concentration was $16 \%$. If the glucose level was higher than $16 \%$, the dilution would be done, if the glucose level was lower than $16 \%$, the addition of pure glucose would be done. 
Figure 3 showed the effect of glucose level to bacillus volume. The greater amount of an additional bacillus volume, the greater glucose level would be gained. The Bacillus volume between 3-9 (\%v/v) showed the increasing of glucose concentration, because that condition was growing phase of Bacillus, so the cellulose containing in bulrush turned into glucose. On the Bacillus volume above $9 \%$, the graph showed constatnt, this was caused by the decreasing of Bacilus performance by time to time then they finally died, so it was necessary to regenerate Bacillus. The yield glucose concentration on hidrolysis process by using Bacillus was $10 \%$, while by using $\mathrm{HCl}$ was $37 \%$, so the glucose concentration by using Bacillus was lower than by using $\mathrm{HCl}$, because chemical process for glucose concentration was higher than biological process, however biological process was more enviromental friendly.

\section{Fermentation Process}

The using fermentation process was the fermentation process which is not used oxygen, in other word, anaerobic process. To control the production of ethanol from sugar was quite complex because the concentration of substrate and oxygen influenced yeast metabolism, cell survival, cell growth, cell division, and ethanol production. The selection of a suitable SC, high concentration tolerance, and substrate were an essential point for improving the ethanol concentration and yield. The most important points in fermentation were starter preparation, inoculation process, until it was completely ready to be put into fermentation tank.

Figure 4 showed the best filtrate fermentation process from bulrush hydrolysis result was in 250 grams bulrush, 8 , 10 , and $12(\%)$ starter additions (liquid SC), fermentation time of $4,5,6,7$, and 8 days. The addition of $10 \%$ starter of liquid volume showed the higher ethanol concentration than $8-12 \%$ starter addition. Then, the remaining glucose level was analyzed. The addition of $10 \%$ starter showed the lower remaining glucose level compared to the addition of $8-12 \%$ starter. After 6 days, the remaining glucose level was higher, because Bacillus performance became weaker and SC regeneration was done. After fermentation process was done on 250 grams bulrush, $10 \%$ SC starter, and 6 days, it was gained ethanol concentration of $31,7 \%$, ethanol concentration in our research was higher than the research conducting by Balat et al., (2008), Nibedita et al., (2012), and Saravana et al., (2014) which was under $16 \%$.

\section{Batch Distillation Process}

Batch distillation process was conducted on temperature of $78^{\circ} \mathrm{C}$, completed by total condensor and gas stove heating, after bottom solution volume remained $10 \%$ from initial volume, batch distillation was stopped.

Table 4 showed the best result of batch distillation process from fermentation process was on $10 \%$ SC starter and 6 days fermentation time. After hidrolysis and fermentation process were done on 250 grams bulrush, $10 \%$ SC starter and 6 days fermentation time, it was obtained $96 \%$ ethanol concentration and 33,3\% ethanol yield. Ethanol concentration from our research result was higher than the research conducting by Alok et al., (2012), 77, 54\% and ethanol yield resulting in our research was economically profitable.

\section{Conclusion}

Based on the aim of research in reviewing hidrolysis process, fermentation process, and batch distillation process, and also searching for alternative material of bioethanol product. The gaining glucose level in the hydrolysis process was $37.8 \%$, ethanol level in the fermentation process was $31,7 \%$, ethanol level in the batch distillation process was $31,69 \%$. The bulrush as material using to product bioethanol, ethanol concentration of $96 \%$ fulfilled the requirement as technical ethanol economically, which was 95\% and ethanol yield level of $33,3 \%$ was enable to be commercialized in pilot plan scale.

TABLE 4. ETHANOL CONSENTRATION AND YIELD ON DISTILLATION BATCH

\begin{tabular}{|c|c|c|c|}
\hline $\begin{array}{c}\text { Time } \\
\text { fermentation }\end{array}$ & $\begin{array}{c}\text { Starter } \\
\text { SC }\end{array}$ & $\begin{array}{l}\text { Ethanol consentratio } \\
\text { distillation }\end{array}$ & $\begin{array}{c}\text { Ethanol } \\
\text { yield }\end{array}$ \\
\hline [day] & [\%] & {$[\%]$} & [\%] \\
\hline 4 & \multirow{5}{*}{8} & 91.5 & 30.5 \\
\hline 5 & & 93 & 31.8 \\
\hline 6 & & 94 & 32.3 \\
\hline 7 & & 92.5 & 31.6 \\
\hline 8 & & 91 & 32.3 \\
\hline 4 & \multirow{5}{*}{10} & 92 & 30.2 \\
\hline 5 & & 94.5 & 31.8 \\
\hline 6 & & 96 & 33.3 \\
\hline 7 & & 95 & 32.6 \\
\hline 8 & & 94 & 32.1 \\
\hline 4 & \multirow{5}{*}{12} & 94 & 30.4 \\
\hline 5 & & 94.5 & 32.8 \\
\hline 6 & & 95 & 33.1 \\
\hline 7 & & 94.5 & 32.9 \\
\hline 8 & & 93 & 32.6 \\
\hline
\end{tabular}

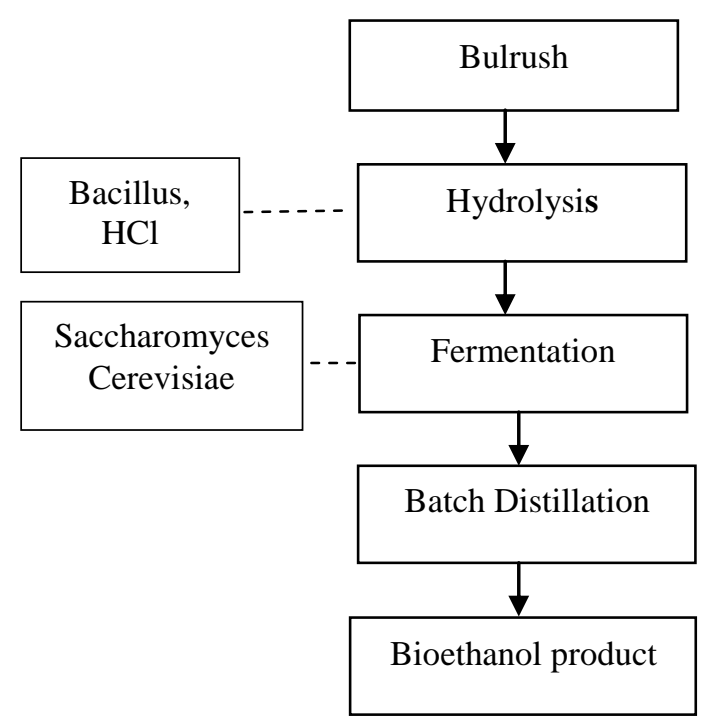

Figure 1. Bioethanol production flow used hydrolysis process, fermentation process, and batch distillation 


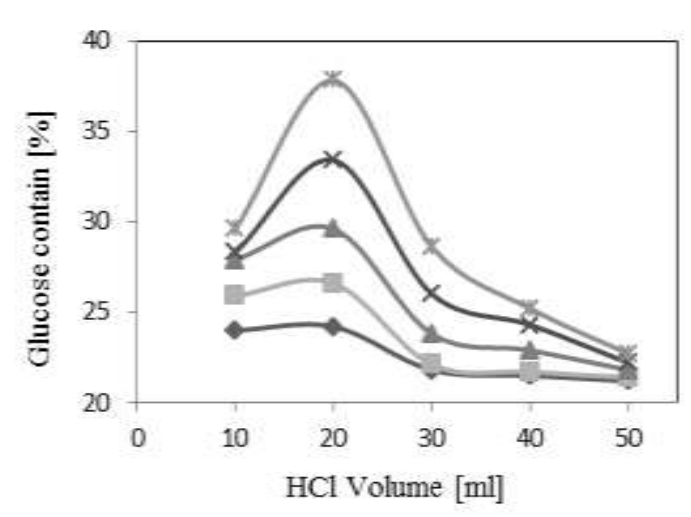

Figure 2. Changes glucose contains with addition $\mathrm{HCl}$ volume in bulrush (50 gram bulrush: $\bullet, 100$ gram bulrush: $\mathbf{\square}, 150$ gram bulrush: $\mathbf{\Lambda}, 200$ gram bulrush: x, 250 gram bulrush: *)

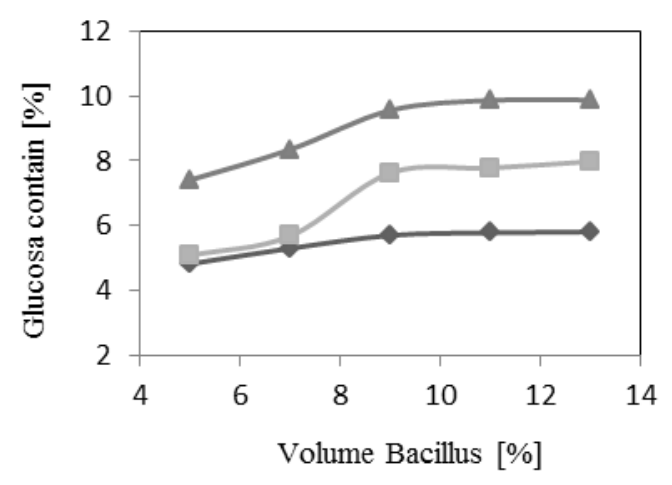

Figure 3. Changes glucose contains with addition volume bacillus in bulrush, (ratio bacillus/volume filtrate $=1: 2$ : ratio bacillus /volume filtrate $=5: 4: \mathbf{a}$, ratio bacillus/volume filtrate $=10: 7:$

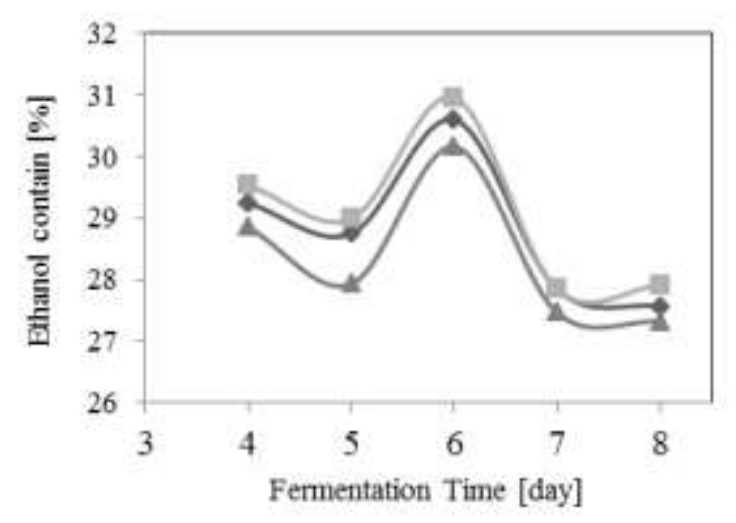

Figure 4. Changes glucose contains with fermentation time in bulrush (200 gram bulrush: •, 250 gram bulrush: $\mathbf{}, 100$ gram bulrush: $\Delta$ )

\section{Acknowledgment}

The authors would like to acknowledge the financial support of the Ministry of National Education of the Republic of Indonesia with the National Strategic Competitive Grant, Contract Number: 180/SP2H/PL/DIT.LITABMAS/V/2013.

\section{References}

[1] A. Demirbas, "Competitive Liquid Biofuels from Biomass," Applied Energy, vol. 88, pp. 17-28, 2011.

[2] Renu Singh, Monika Srivastava, and Ashish Shukla, "Environmental sustainability of bioethanol production from rice straw in India: A review", Renewable and Sustainable Energy Reviews, vol. 54, pp. 202-216, 2016.

[3] A. Kumar, L. K. Singh, and S. Ghose, "Bioconversion of Lignocellulosic Fraction of Water-Hyacinth (Eichhornia Crassipes) HemicelluloseAcid Hydrolysate to Ethanol by Pichia Stipitis," Bioresource Technology, vol. 100, pp. 3293-3297, 2009.

[4] A. K. Dubey, P. K. Gupta, N. Garg, and S. Naithani, "Bioethanol Production from Waste Paper Acid Pretreated Hydrolyzate with Xylose Fermenting Pichia Stipitis," Carbohydrate Polymers, vol. 88, pp. 825$829,2012$.

[5] A. Demirbas, "Product from lignocellulosic material via degradation processes," Energy Sources, vol. 30, no. 1, pp. 27-37, 2008.

[6] M. Tutt, T. Kikas, and J. Olt, "Influence of different pretreatment methods on bioethanol production from wheat straw," Agronomy Researt Biosystem Engineering, vol. 1, pp. 269-276, 2012.

[7] Edem Cudjoe Bensah, and Moses Mensah, "Chemical Pretreatment Methods for the Production of Cellulose Ethanol: Technologies and Innovations," Research Article, vol. 2013, Article ID 719607, 21 pages, http://dx.doi.org/10.1155/2013/719607.

[8] Iliana Barrera, A. Myriam, H. Alizadeh, and AmezcuaAllieri, "Technical and economical evaluation of bioethanol production from lignocellulosic residues in Mexico: Case of sugarcane and blue agave bagasses," Chemical Engineering Research and Design, vol. 107, pp. 91-101, 2016.

[9] Nicolas Brosse, Mohamad Nasir Mohamad Ibrahim, and Afidah Abdul Rahim, "Biomass to Bioethanol: Initiatives of the Future for Lignin," Review Article, vol. 2011, Article ID 461482, 10 pages, doi:10.5402/2011/461482.

[10] Federico Battista, Giuseppe Mancini, Bernardo Ruggeri, and Debora Fino, "Selection of the best pretreatment for hydrogen and bioethanol production from olive oil waste products,"Renewable Energy, vol. 88, pp. 401-407, 2016.

[11] Yun Liu, Hua Zhou, Shihui Wang, Keqin Wang, and Xiaojun $\mathrm{Su}$, "Comparison of $\gamma$-irradiation eith other pretreatments followed with simultaneous saccharification and fermentation on bioconversion of microcrystalline cellulose for bioethanol production," Bioresource Technology, vol.182, pp. 289-295, 2015.

[12] Indra Neel Pulidindi, B. Baruchi Kimchi, and Aharon Gedanken, "Can cellulose be a sustainable feedstock for bioethanol production ?," Renewable Energy, vol. 71, pp. 77-80, 2014.

[13] A. Limayem, and S. C. Ricke, "Ligocellulosic Biomass for Bioethanol Production: Current Perspectives, Potential Issues and Future Prospects,"Progress in Energy Combustion Science, vol. 38, pp. 449-67, 2012. 
Proc. of The Seventh Intl. Conf. On Advances in Applied Science and Environmental Technology - ASET 2017 Copyright (C) Institute of Research Engineers and Doctors, USA .All rights reserved.

ISBN: 978-1-63248-136-8 doi: 10.15224/ 978-1-63248-136-8-22

[14] Hongzhang Chen, and Xiaoguo, "Industrial technologies for bioethanol production from lignocellulosic biomass," Renewable and Sustainable Energy Reviews, vol. 57, pp. 468-478, 2016.

[15] Menghui Yu, Jihong Li, Sandra Chang, Lei Zhang and Shizhong Li, "Bioethanol production using sodium hydroxide pretreated sweet sorghum bagasse without Washing," Fuel, vol. 175, pp. 20-25, 2016.

[16] N. Sarkar, S. K. Ghosh, S. Bannerjee, and K. Aikat, "Bioethanol Production from Agricultural Wastes: An Overview," Renewable Energy, vol. 37, pp. 19-27, 2012.

[17] K. Karimi, S. Kheradmandinia, and M. J. Taherzadeh, "Conversion of Rise Straw to Sugars by Dilute Acid Hydrolysis," Biomass and Bioenergy, vol. 30, pp. 247253, 2006.

[18] M. Balat, H. Balat, and O. Cahide, "Progress in Bioethanol Processing," Progress in Energy Combustion Science, vol. 34, pp. 551-73, 2008.

[19] N. Sarkar, S. K. Ghosh, S. Bannerjee, and K. Aikat, "Bioethanol Production from Agricultural Wastes: An Overview," Renewable Energy, vol. 37, pp. 19-27, 2012.

[20] R. C. Kuhad, R. Gupta, Y. P. Khasa, and A. Singh, "Bioethanol Production from Lantana Camara (Red Sage): Pretreatment, Saccharification and Fermentation," Bioresource Technology, vol. 101, pp. 8348-8354, 2010.

[21] S. K. Thangavelu, A. S. Ahmed, and F. N. Ani, "Bioethanol Production from Sago Pith Waste Using Microwave Hydrothermal Hydrolysis Accelerated by Carbon Dioxide," Applied Energy, vol.128, pp. 277283, 2014.

[22] Evanie Devi Deenanath, Karl Rumbold and Sunny Iyuke, "The Production of Bioethanol from Cashew Apple Juice by Batch Fermentation Using Saccharomyces cerevisiae Y2084 and Vin13," Research Article, vol. 2013, Article ID 107851, 11 pages, http://dx.doi.org/10.1155/2013/107851.

[23] G. Sathya Geetha, A. Navaneetha Gopalakrishnan, "Bioethanol production from Paper Fibre Residue Using Diluted Alkali Hydrolysis and the Fermentation Process," E-Journal of Chemistry, vol. 8, no. 4, pp. 1951-1957, 2011.

[24] Wei Han, Zhanqing Wang, Hong Chen, Xin Yao, and Yongfeng Li, "Simultaneous Biohydrogen and Bioethanol Production from Anaerobic Fermentation with Immobilized Sludge," Research Article, vol. 2011, Article ID 343791, 5 pages, doi:10.1155/2011/343791.

[25] E.J. Henley, J.D. Seader and D.K. Roper, "Separation Process Principles", $3^{\text {rd }}$ Edition, John Wiley \& Sons, Inc., New York, 2011.

[26] M. Balat, H. Balat and O. Cahide; "Progress in Bioethanol Processing," Prog. Energy. Combust. Sci., vol. 34, pp. 551-73, 2008.

[27] F. Teymouri, L. Laureano-Peres, H. Alizadeh and B. E. Dale; "Optimization of the Ammonia Fiber Explosion (AFEX) Treatment Parameters for Enzymatic Hidrolysis of Corn Stover," Biores. Tech., vol. 96, pp. 2014-2018, 2005.
[28] S.K. Thangavelu, A. S. Ahmed and F. N. Ani; "Bioethanol Production from Sago Pith Waste Using Microwave Hydrothermal Hidrolysis Accelerated by Carbon Dioxide," Appl. Energ., vol. 128, pp. 277-283, 2014.

[29] J.S. Lim, Z. Abdul Manan, S.R. Wan Alwi, and H. Hashim, "A review on utilisation of biomass from rice industry as a source of renewable energy," Renewable and Sustainable Energy Reviews, vol. 16, no. 5, pp. 3084-3094, 2012.

[30] Y.Z. Pang, Y.P. Liu, X.J. Li, K.S. Wang, and H.R. Yuan, "Improving biodegradability and biogas production of corn trover through sodium hydroxide solid state pretreatment," Energi and Fuel, vol. 22, no. 4, pp. 2761-2766, 2008.

[31] J. Gabhane, S.P.M. Prince William, A.N. Vaidya, K. Mahapatra, and T. Chakrabarti, "Influence of heating source on the afficacy of cellulosic pretreatment-a cellulosic ethanol perspective," Biomass and Bioenergy, vol. 35, no. 1, pp. 96-102, 2011.

[32] Y. Kim, R. Hendrickson, N.S. Mosier et al., "Enzyme hydrolysis and ethanol fermentation of liquid hot water and AFEX pretreated distillers' grains at hight-solids loadings," Bioresource Technology, vol. 99, no. 12, pp. 5206-5215, 2008.

[33] J.S. Lee, B. Parameswaran, J.P. Lee, and S.C. Park, "Recent development of key technologies on cellulosic ethanol production," Journal of Scientific and Industrial Research, vol. 67, no. 11, pp. 965-873, 2008.

[34] Y. Li, R. Ruan, P.I. Chen et al., "Enzymatic hydrolusis of corn stover pretreated by combined dilute alkaline treatment and homogenization, "Transactions of the American Society af Agricultural Engineers, vol. 47, no. 3, pp. 821-825, 2004.

[35] P. Harmsen, W. Huijgen, L. Bermudez, and R. Bakker, "Literature riview of physical and chemical pretreatment precesses for lignocellulosic biomass," Tech. Rep. 1184, Biosynergy, Wagenin-gen UR Food \& Biobased Research, 2010.

[36] J.W. Lee and T.W. Jeffries, "Efficiencies of acid catalysts in the hydrolysisof lignocellulosic biomass over a range of combined severity factors," Bioresource Technology, vol. 102, no. 10, pp. 58845890, 2011.

[37] J.S. Van Dyk and B.I. Pletschke,"A review of lignocellulose bio-conversion using enzymes-Factors affecting enzymes, conversion and synergy," Biotechnology Advance, vol. 30, no. 6, pp. 1458-1480, 2012.

[38] J.D. McMillan, "Bioethanol production: status and prospects," Renewable Energy, vol. 10, no. 2-3, pp. 295-302, 1997.

[39] D.M. Lavenson, E.J. Tozzi, N. Karuna, T.Jeoh, R.I. Powell and M.J. McCarthy, "The effect of mixing on the liquefaction and saccharification of cellulosic fibers," Bioresource Technology, vol. 111, pp. 240247, 2012.

[40]G. Radeva, I. Valchev, S. Petrin, E. Valcheva and P. Tsekova, "Kinetic model of enzymatic hydrolysis of steam-exploted wheat straw," Carbohydrate Polymers, vol. 87, no. 2, pp. 1280-1285, 2012. 
Proc. of The Seventh Intl. Conf. On Advances in Applied Science and Environmental Technology - ASET 2017 Copyright (C) Institute of Research Engineers and Doctors, USA .All rights reserved.

ISBN: 978-1-63248-136-8 doi: 10.15224/ 978-1-63248-136-8-22

[41] Y. Sun and J. Cheng, "Hydrolysis of lignocellulosic materials for ethanol production: a review," Bioresource Technology, vol. 83, no. 1, pp. 1-11, 2002.

About Author (s):

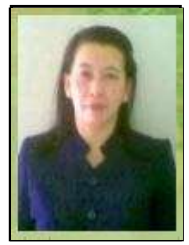

Our research on the bioethanol production, and simulation of chemical engineering. The research have been upload in Google Scoolar on behalf of Ni Ketut Sari. In addition we also obtained a grant from the Government of Indonesia through the Ministry of Research and Higher

Education Technology, i.e., a graduate of grant of Pascasarjana, grant of Bersaing, grant of Strategi Nasional, and grants of Kompetensi. 